\title{
PENELITIAN MORFOLOGI TERITISAN DENGAN SISTEM KINETIK DAN EFEKTIFITASNYA PADA BANGUNAN KANTOR
}

\author{
Firza Utama Sjarifudin \\ Architecture Department, Faculty of Engineering, Binus University \\ Jl. K.H. Syahdan No. 9, Palmerah, Jakarta Barat 11480 \\ firzarsitek@yahoo.co.jp
}

\begin{abstract}
Shading device serves as a shade and protection against negative influences caused by the uncertain external conditions. This article discusses the study of kinetic shading system and evaluates its effectiveness against a wide range of environmental factors and their effects on building. The study performs simulation of thermal factors, day lighting, airflow, and energy generation. Morphological types of shading device to be tested are systems of overhang, folded, horizontal louvre, and vertical louvre. The test results demonstrate that kinetic system obtains more advantages and effectiveness than the standard and static systems do. Therefore, it can be concluded that this study is able to be used as a reference for designing kinetic shading device which is responsive to environmental factors.
\end{abstract}

Keywords: shading device, kinetic system, environmental simulation

\begin{abstract}
ABSTRAK
Teritisan pada bangunan berfungsi sebagai peneduh dan pelindung terhadap pengaruh negatif yang disebabkan oleh tidak menentunya kondisi eksternal. Makalah ini akan membahas studi bentuk teritisan dengan sistem kinetik serta menguji efektifitasnya terhadap berbagai macam faktor lingkungan dan pengaruhnya terhadap bangunan perkantoran. Metode yang digunakan dalam penelitian ini adalah pengujian simulasi terhadap faktor solar thermal, daylighting, aliran udara, dan penghasilan energi. Morfologi bentuk dari jenis teritisan yang diuji adalah sistem overhang, lipat, sirip horizontal, dan sirip vertikal. Hasil memperlihatkan keunggulan dan efektifitas dapat dihasilkan lebih dengan sistem kinetik dibandingkan dengan sistem standard dan statis. Sehingga dapat disimpulkan bahwa penelitian ini dapat dipergunakan sebagai acuan untuk merancang sebuah teritisan kinetik yang tanggap terhadap faktor lingkungan.
\end{abstract}

Kata kunci: teritisan, sistem kinetik, simulasi lingkungan 


\section{PENDAHULUAN}

Kebanyakan orang menghabiskan hingga 90\% dari waktu mereka di dalam ruangan (Bougdah dan Sharples, 2010) sehingga banyak usaha yang dilakukan untuk membuat bangunan yang aman, sehat dan senyaman mungkin. Teritisan pada bangunan menyediakan tempat penampungan dan perlindungan terhadap pengaruh negatif yang disebabkan oleh tidak menentunya kondisi eksternal.

Pada saat ini dinilai sangat penting untuk mempertimbangkan kembali peran teritisan bangunan, bukan hanya menjadi peneduh, teritisan pada bangunan juga dapat dirancang dengan fungsi-fungsi vital yang menentukan konsumsi energi bangunan dan kualitas lingkungan dalam ruangan. Secara tradisional, kebanyakan teritisan bersifat 'statis', sedangkan kondisi iklim dan preferensi pengguna yang terus berubah. Akibatnya sistem teritisan tradisional tidak dapat beradaptasi dengan perubahan itu, dan ini mengakibatkan hilangnya kesempatan untuk penghematan energi dan meningkatkan kenyamanan termal dan visual penghuni.

Di sisi lain sistem teritisan kinetik yang ditawarkan dalam penelitian ini mendefinisikan teritisan dengan cara yang berbeda secara mendasar. Teritisan dengan sistem kinetik secara aktif dapat menyesuaikan perilaku bentuk dari waktu ke waktu sebagai respon terhadap perubahan kondisi lingkungan dan persyaratan kinerja. Teritisan dengan sistem kinetik memiliki kemampuan untuk memanfaatkan energi alami yang tersedia di lingkungan kita dengan cara yang jauh lebih efektif. Teritisan dengan sistem kinetik tidak hanya menawarkan potensi untuk mengurangi penggunaan energi untuk penerangan, tapi pada saat yang sama juga diharapkan untuk dapat menghasilkan kontribusi positif terhadap kualitas dan tingkat kenyamanan termal dan visual.

\section{METODE}

Metode yang digunakan untuk mengkaji efektivitas sistem kinetik adalah dengan melakukan pengujian dengan menggunakan beberapa simulasi komputer yang kemudian hasil dari simulasi tersebut dibandingkan untuk menemukan kelebihan dan kekurangan dari teritisan kinetik. Jenis teritisan kinetik yang diuji adalah: overhang, lipat, sirip vertikal, sirip horizontal. Masing-masing jenis teritisan tersebut kemudian diujikan terhadap beberapa aspek lingkungan dengan melakukan simulasi: solar thermal, daylighting, aliran udara, dan energi. Beberapa program komputer yang digunakan untuk melakukan simulasi tersebut adalah sebagai berikut: (1) Ecotect Analysis untuk mensimulasikan konsumsi energi yang dibutuhkan untuk pendinginan, dan intensitas pencahayaan alami pada ruang; (2) CFD-ACE + untuk mensimulasikan aliran udara; (3) Solar Advisor Model untuk mensimulasikan efektifitas energi yang dibutuhkan untuk pengoperasian objek kinetik.

Fungsi bangunan yang dikaji pada penelitian ini adalah perkantoran dengan bentuk ruang tipikal 1.40 grid module yang diambil dari Architects' Data. Ukuran model ruang yang dipakai adalah $4.40 \mathrm{~m}$ x $15.1 \mathrm{~m}$ dengan bukaan jendela di satu sisinya (Gambar 1). Meja diletakkan dengan jarak 0.3m di samping jendela, ketinggian floor to floor $3.22 \mathrm{~m}$. Jendela diletakkan sepanjang sisi bangunan $0.78 \mathrm{~m}$ dari lantai, dengan tinggi jendela $1.24 \mathrm{~m}$. Untuk pengkajian aliran udara, diasumsikan $1 / 2$ dari bagian jendela dapat dibuka/tutup.

Untuk penelitian kali ini empat jenis model fasade kinetik dipilih dengan pertimbangan bentuk yang umum dan sederhana (Gambar 2). Bentuk dan sistem kinetik dari jenis-jenis teritisan tersebut adalah sebagai berikut: Sistem overhang dengan bentuk bidang external horizontal yang bergantung jepit pada bagian atas jendela - pergerakan yang dapat dihasilkan adalah berputar secara vertikal dari $0^{0}$ sampai $90^{\circ}$. Sistem lipat merupakan bentuk dua bidang yang saling bertemu di salah satu ujungnya 
dan bagian bawah dapat bergeser searah vertikal jendela yang menghasilkan gerakan melipat. Sistem sirip merupakan bentuk deretan bidang-bidang yang sejajar secara vertikal maupun horizontal deretan bidang tersebut dapat berputar pada masing-masing porosnya.

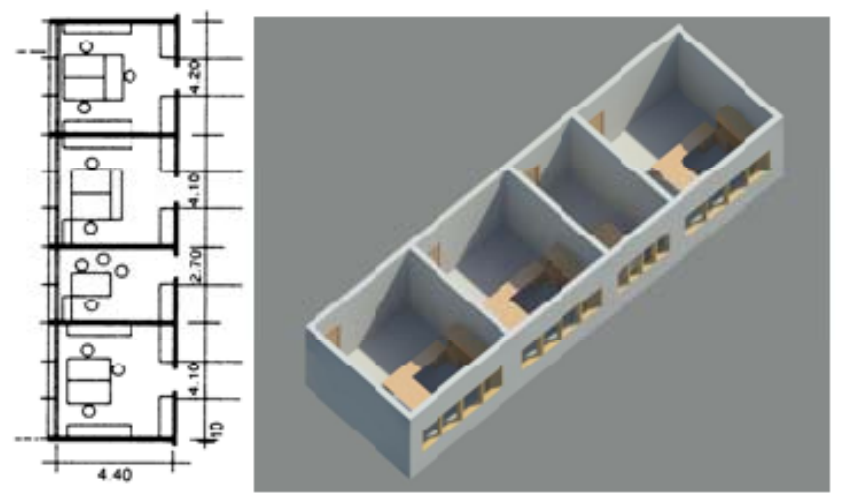

Gambar 1. Denah ruang kantor (kiri), model ruang 3D yang akan diuji (kanan).

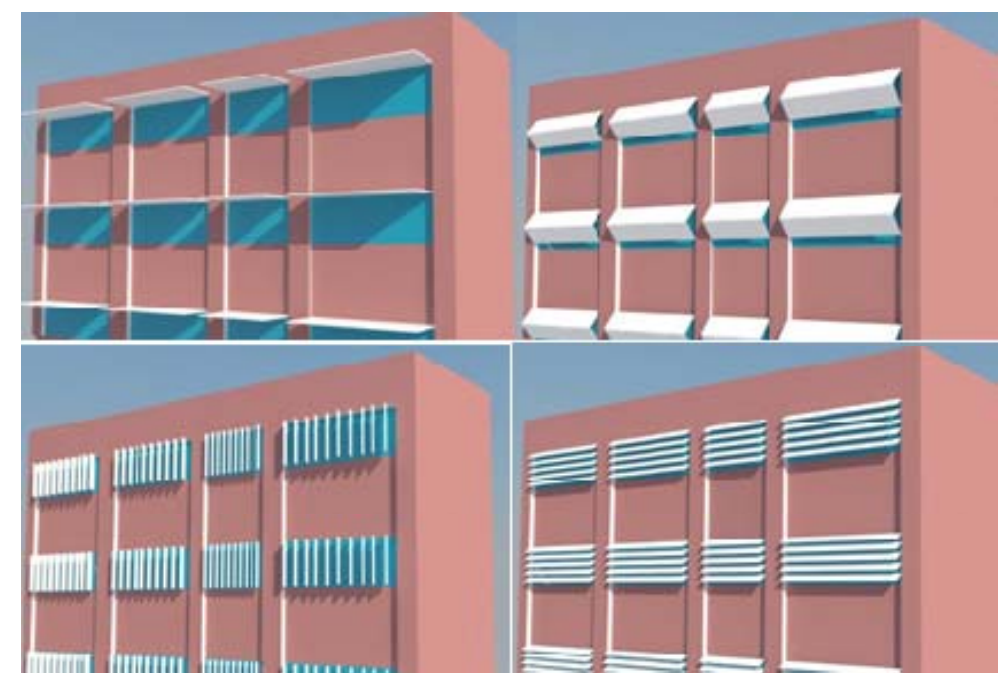

Gambar 2. Sistem teritisan (dari kiri atas searah jarum jam): overhang, lipat, sirip horizontal, sirip vertikal.

\section{Simulasi Solar Thermal}

Pada simulasi ini dilakukan perbandingan antara empat jenis sistem kinetik terhadap kondisi thermal. Pengujian pertama dilakukan pada model bangunan tanpa sistem teritisan eksternal yang merupakan bentuk model bangunan secara umum. Tujuan dari penggunaan model ini adalah sebagai acuan dasar perbandingan terhadap jenis-jenis sistem teritisan.

Pengujian kedua dilakukan pada jenis sistem overhang dengan pengaturan sudut perputaran dari $0^{\circ}$ (vertikal), $30^{\circ}, 60^{\circ}$, dan $90^{\circ}$ (horizontal). Lebar overhang adalah $1.24 \mathrm{~m}$ sehingga dapat menutupi seluruh permukaan jendela pada keadaan vertikal.

Pengujian ketiga dilakukan pada jenis sistem lipat dengan pengaturan sudut perputaran yang sama dengan sistem overhang. Dua buah bidang dengan lebar 0.6m yang dapat diputar pada poros 
tengahnya digunakan dalam model ini sehingga menghasilkan bentuk lipatan. Efek teritisan dari sistem ini adalah $1 / 2$ dari sistem overhang tetapi dapat menghasilkan covering lebih banyak terhadap jendela.

Pengujian keempat dilakukan pada sistem sirip horizontal dengan pengaturan sudut perputaran yang sama dengan pengujian sebelumnya. Lebar dari setiap sirip pada sistem ini adalah $0.12 \mathrm{~m}$. Efek yang dihasilkan dari bentuk ini adalah jarak antara jendela dan teritisan yang statis.

Pengujian kelima dilakukan pada sistem sirip vertikal dengan dengan pengaturan sudut perputaran pada masing-masing poros tengah sirip - besar sudut yang diuji sama dengan sistem sebelumnya. Efek yang dihasilkan dari bentuk ini adalah berorientasi vertikal terhadap bangunan sehingga dapat secara langsung mengikuti alur posisi matahari dalam sehari. Simulasi pada masingmasing sistem di atas dilakukan untuk menghasilkan laporan konsumsi listrik yang digunakan untuk pendinginan dalam $\mathrm{kWh}$. Setiap sistem tersebut kemudian saling dibandingkan untuk menemukan performa terbaik setiap jamnya. Untuk menunjukkan hasil dari sistem kinetik dilakukan melalui proses iteratif dengan membuat sebuah sistem gabungan dari setiap sistem dengan mencari sudut yang terbaik dalam setiap jamnya. Gambar 3 di bawah ini memperlihatkan contoh simulasi Solar Thermal.

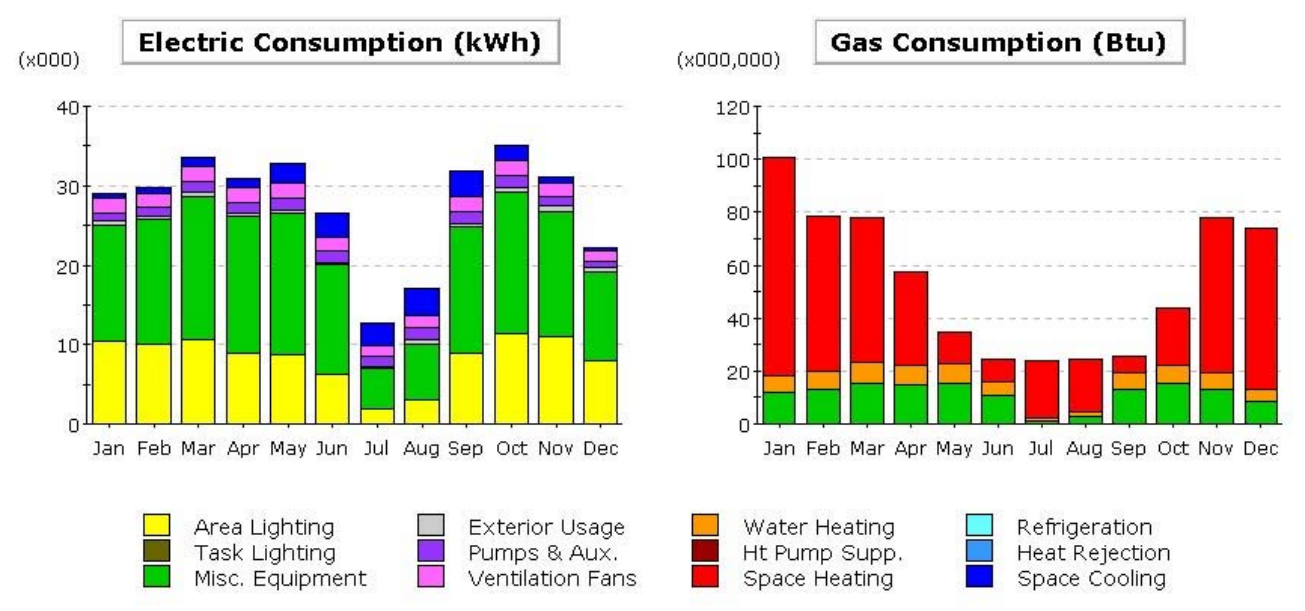

Gambar 3. Contoh simulasi Solar Thermal.

\section{Simulasi Daylighting}

Simulasi untuk daylighting dilakukan pada sistem yang sama dengan empat sudut yang berbeda pengaturannya masing-masing. Sistem daylight diatur pada posisi Jakarta, lightmeter diletakkan pada meja dengan ketinggian $0.78 \mathrm{~m}$, tinggi berdiri $1.7 \mathrm{~m}$. Kondisi langit menggunakan CIE Clear Sky model. Output data dari simulasi kemudian dimasukkan dalam spreadsheet untuk dilakukan perbandingan antara sistem. Daylight level dibandingkan dengan tingkat pencahayaan yang direkomendasikan untuk kategori D gedung perkantoran (200-500 lux). Jumlah titik lightmeter kemudian dihitung. Titik yang berada pada kisaran yang direkomendasikan untuk waktu tertentu dijumlahkan untuk menemukan jumlah titik yang jatuh pada permukaan. Untuk mensimulasikan gerakan kinetik sebuah sistem gabungan kembali digunakan dengan mengambil pengaturan sudut yang menghasilkan jumlah titik terbanyak dalam kisaran waktu yang direkomendasikan. Gambar 4 memperlihatkan contoh simulasi daylighting. 


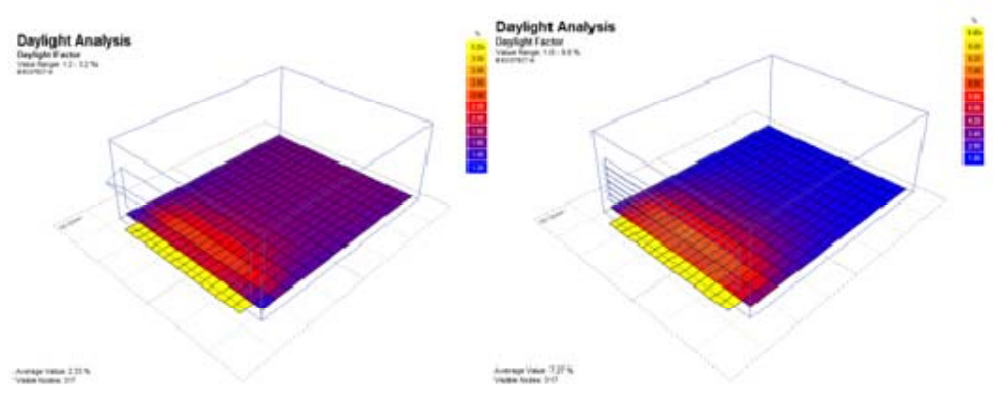

Gambar 4. Contoh simulasi Daylighting.

\section{Simulasi Aliran Udara}

Tujuan dari simulasi aliran udara pada sistem kinetik adalah untuk mengukur kemampuan pergerakan udara alami dalam ruang. Standar kenyamanan thermal yang dipengaruhi oleh pergerakan udara digunakan untuk menentukan performa aliran udara. Simulasi CFD (Gambar 5) dilakukan untuk membandingkan secara kuantitatif air flow rate dalam meter per detik dari jenis-jenis sistem. Dalam pengujian kondisi kecepatan angin model bangunan dibuat dengan bagian bawah jendela yang dapat beroperasi dalam keadaan terbuka. Pengaturan grid analisa dibuat melebihi batas bangunan untuk dapat memperhitungkan inlet dan outlet dari batasan lingkungan. Iterasi yang diterapkan pada simulasi ini sebanyak 200 untuk setiap sistem kinetik terhadap beberapa sudut dari arah prevailing wind.

\section{Simulasi Energi}

Pada simulasi penghasilan energi (Gambar 6) yang dibutuhkan untuk sistem kinetik tidak menggunakan model 3D melainkan input dari penempatan dan data sistem kinetik. Data penting yang digunakan adalah lokasi, luas penampang, altitude dan azimuth dari panel, dan tipe solar panel. Pengaturan diterapkan pada jenis Building Integrated Photovoltaic (BIPV) yang diletakkan pada jendela vertikal $\left(0^{0}\right)$. Pengujian dilakukan pada fasade sisi Utara. Jumlah energi yang dihasilkan dari tiap pengaturan kemudian dimasukkan dalam spreadheet dimana jumlah total dari dari energi yang dihasilkan dalam kWh dapat disortir untuk menemukan performa terbaik, dan sistem gabungan untuk mengetahui tingkat tertinggi penghasilan energi.

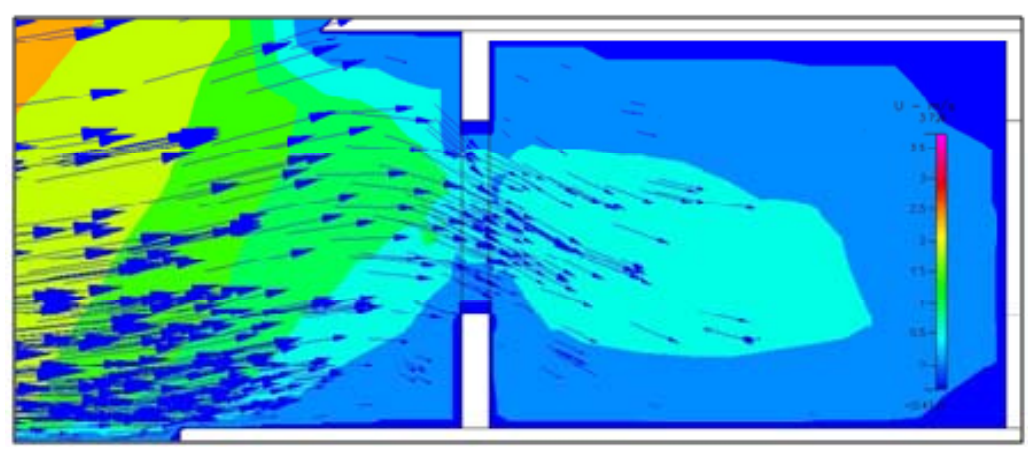

Gambar 5. Contoh simulasi CFD untuk aliran udara. 


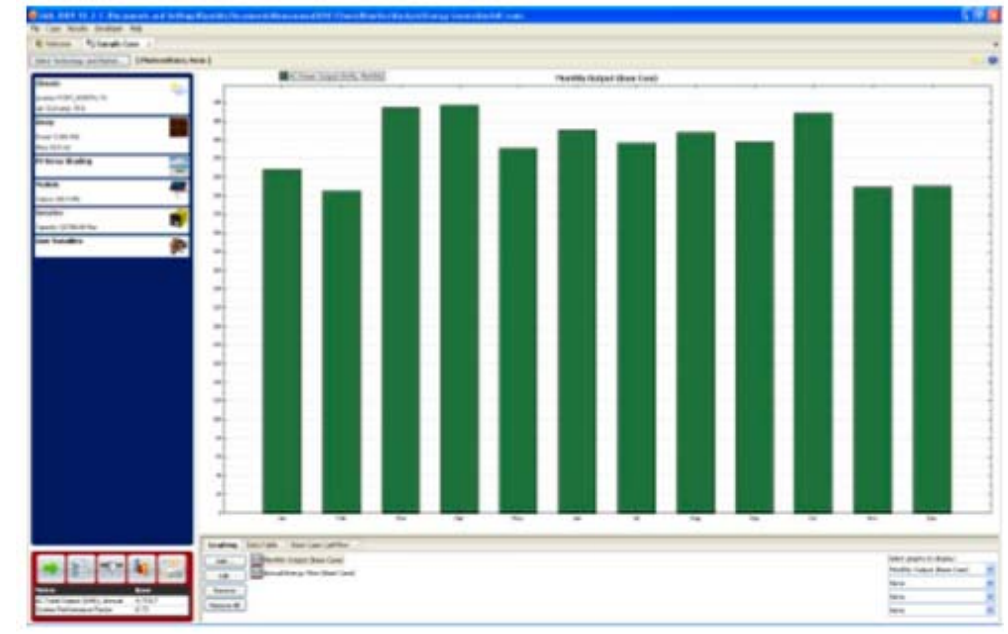

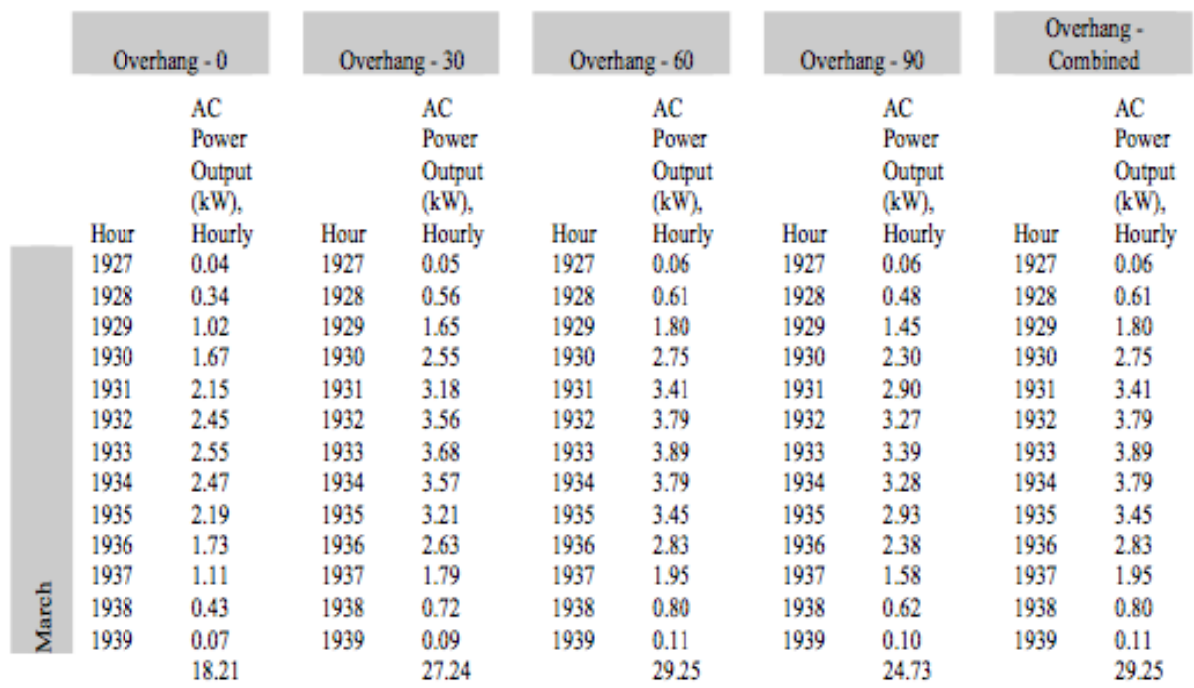

Gambar 6. Contoh simulasi penghasilan energi.

\section{HASIL DAN PEMBAHASAN}

\section{Hasil Solar Thermal}

Hasil dari laporan konsumsi penggunaan listrik untuk pendinginan ditunjukkan dalam persentase peningkatan dan penurunan pada sistem kinetik dibandingkan dengan tanpa teritisan (Tabel 1). Berdasarkan dari hasil simulasi, dapat dilihat bahwa sistem kinetik dapat menghasilkan penurunan konsumsi energi sekitar 30\% dibandingkan dengan tanpa teritisan, kemudian pada sistem overhang dan sirip horizontal menghasilkan jumlah penurunan terbesar sebanyak 33\% untuk pendinginan.

Tabel 1

Hasil simulasi Solar Thermal

\begin{tabular}{lccc}
\hline Pendinginan & kWh & $\begin{array}{c}\text { Penurunan } \\
\text { kWh }\end{array}$ & $\begin{array}{c}\text { Persentase } \\
\text { Penurunan }\end{array}$ \\
\hline Tanpa Teritisan & 128.040 & $\mathrm{x}$ & $\mathrm{x}$ \\
\hline
\end{tabular}




\begin{tabular}{llll}
\hline Overhang & 85.820 & 42.220 & $33 \%$ \\
\hline Lipat & 86.180 & 41.860 & $32.7 \%$ \\
\hline Sirip horizontal & 85.460 & 42.580 & $33.3 \%$ \\
\hline Sirip vertikal & 92.002 & 36.038 & $28.1 \%$ \\
\hline
\end{tabular}

Penurunan konsumsi energi dari sistem kinetik tersebut dikarenakan oleh lebih lamanya kemampuan untuk menghalang pengaruh matahari yang tidak diinginkan, contohnya pada sistem horizontal dengan posisi tegak lurus terhadap fasade memungkinkan untuk menyaring sinar matahari sepanjang hari, sedangkan sistem vertikal memungkinkan untuk melacak dan menyesuaikan posisinya terhadap sudut matahari. Dari keempat sistem yang diuji dapat dilihat bahwa performa sistem overhang dan sirip horizontal lebih tinggi dibandingkan yang lain. Kedua sistem tersebut lebih baik dibandingkan dengan sistem lipat dikarenakan metode rotasi yang dihasilkan mampu untuk menaungi lebih banyak permukaan pada waktu tertentu, sedangkan sistem lipat hanya dapat berfungsi sebagai naungan horizontal untuk setengah dari ketinggian jendela. Sistem vertikal jika diletakkan pada sisi Utara bangunan tidak dapat memasukkan sinar yang cukup dibandingkan dengan ketiga sistem yang lain.

Secara garis besar perbedaan angka yang didapat sangat dekat satu dengan lainnya dan pengaruhnya cukup minim sehingga dapat disimpulkan bahwa dengan jenis sistem apapun selama menggunakan kinetika di dalamnya akan menghasilkan efisiensi sekitar 30\% lebih baik dibandingkan dengan tanpa teritisan.

\section{Hasil Daylighting}

Tujuan dari simulasi daylight adalah menemukan sistem yang dapat menghasilkan pencahayaan yang masuk dalam kisaran kenyamanan visual secara alami. Sangat dimungkinkan untuk menghasilkan angka di atas yang direkomendasikan (500 lux) dan tetap menghasilkan lingkungan yang nyaman, tetapi angka tersebut dalam hal ini tidak dihitung. Hasil yang dapat dilihat pada Gambar 7 di bawah ini memperlihatkan bahwa sistem tanpa teritisan menghasilkan 0\% yang melambangkan tingkat pencahayaan yang melebihi rekomendasi. Hasil yang perlu diperhatikan pada penelitian sistem kinetik ini adalah variasi tingkat pencahayaan yang dapat masuk ke dalam ruang dalam kisaran yang direkomendasikan pada rentan waktu yang lama.

\section{Hasil Aliran Udara}

Pengaturan sudut dengan jumlah tertinggi dari titik-titik kecepatan yang ada digabungkan untuk membentuk sistem kinetik yang dapat diperbandingkan antar sistem dan tanpa teritisan. Bukaan pada jendela untuk aliran udara terdapat antara $0.78 \mathrm{~m}$ sampai $1.40 \mathrm{~m}$ dari atas lantai yang mana cukup dapat dirasakan oleh pengguna. Hasil dari aliran udara (Gambar 8) dapat dilihat bahwa pengaturan sistem yang terbaik adalah sirip vertikal $60^{\circ}$ menghadap Barat yang menghasilkan ruang dengan kecepatan aliran 0.6 sampai $0.8 \mathrm{~m} / \mathrm{s}$ yang dapat mempengaruhi penurunan suhu $1-2{ }^{\circ} \mathrm{C}$. Secara keseluruhan sistem kinetik dapat meningkatkan kecepatan aliran dengan kisaran antara 0.3 sampai 0.5 $\mathrm{m} / \mathrm{s}$ dengan $0.9 \%$ untuk sistem sirip vertikal, $2.7 \%$ untuk overhang, $6.5 \%$ untuk sirip horizontal, dan 9.7\% untuk sistem lipat. Peningkatan aliran dengan kisaran antara 0.6 samapai $0.8 \mathrm{~m} / \mathrm{s}$ dengan $4.1 \%$ untuk overhang, 5.5\% untuk sirip horizontal, $10.3 \%$ untuk lipat, dan $13.8 \%$ untuk sirip vertikal.

Dari keempat sistem yang diuji, sistem vertikal menghasilkan performa yang lebih baik berkat kemampuannya melacak arah angin dari segala arah. Sistem horizontal hanya dapat diuji terhadap angin yang datang dari ketinggian yang sama. Sistem kinetik menghasilkan sedikit peningkatan daripada bukaan jendela biasa, dengan kecepatan angin sebesar 0.25 sampai $1.02 \mathrm{~m} / \mathrm{s}$ sedangkan bukaan biasa sebesar 0.5 sampai $20.9 \mathrm{~m} / \mathrm{s}$. 


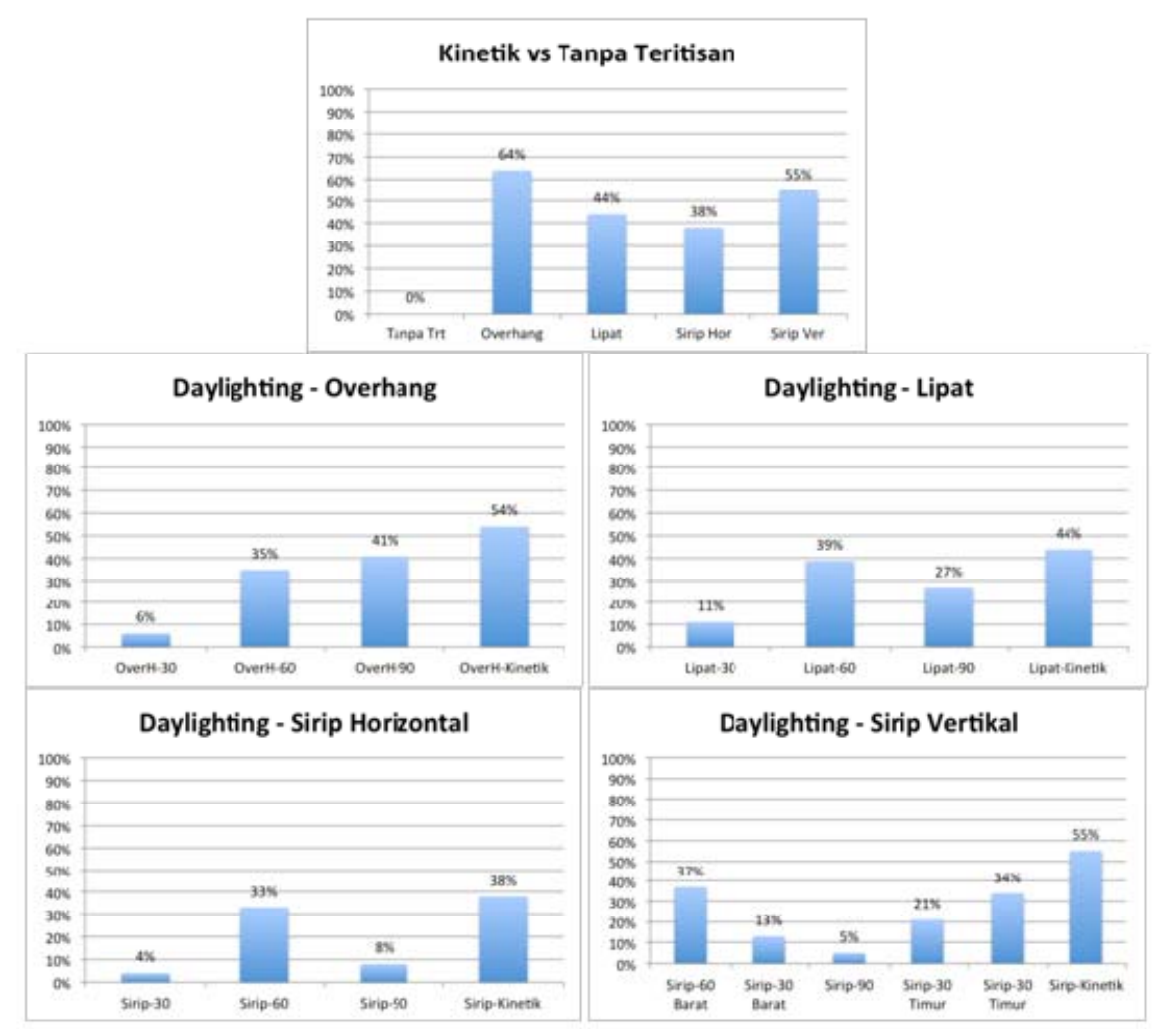

Gambar 7. Hasil simulasi daylighting sistem kinetik.

\begin{tabular}{lrrrrrrrrrrrrr}
\hline \multicolumn{1}{c}{$\begin{array}{c}\text { Kecepatan } \\
\text { (m/s) }\end{array}$} & $\mathbf{0 . 0}$ & $\mathbf{0 . 1}$ & $\mathbf{0 . 2}$ & $\mathbf{0 . 3}$ & $\mathbf{0 . 4}$ & $\mathbf{0 . 5}$ & $\mathbf{0 . 6}$ & $\mathbf{0 . 7}$ & $\mathbf{0 . 8}$ & $\mathbf{0 . 9}$ & $\mathbf{1 . 0}$ & $\mathbf{1 . 1}$ & $\mathbf{1 . 2}$ \\
\hline Tanpa Trt & 11.5 & 28.8 & 34.1 & 10.5 & 6.1 & 4.3 & 4.4 & 0.4 & 0 & 0 & 0 & 0 & 0 \\
Overhang-30 & 32.7 & 54.3 & 13 & 0 & 0 & 0 & 0 & 0 & 0 & 0 & 0 & 0 & 0 \\
Overhang-60 & 28.4 & 31.6 & 12 & 10.5 & 9 & 4.7 & 3.8 & 0 & 0 & 0 & 0 & 0 & 0 \\
Overhang-90 & 24.2 & 32.2 & 13.7 & 10 & 6.7 & 6.8 & 5.2 & 1 & 0 & 0 & 0 & 0 & 0 \\
Overhang-Kin & 24.2 & 32.2 & 13.7 & 10 & 6.7 & 6.8 & 5.3 & 1 & 0 & 0 & 0 & 0 & 0 \\
Lipat-30 & 8.2 & 32.4 & 23.4 & 12.3 & 9.8 & 8.5 & 3.7 & 0.9 & 0.8 & 0 & 0 & 0 & 0 \\
Lipat-60 & 13.3 & 36 & 23.7 & 9.7 & 6.3 & 4.9 & 4.9 & 1.3 & 0 & 0 & 0 & 0 & 0 \\
Lipat-90 & 8.4 & 25 & 29.6 & 18.1 & 7.9 & 5 & 4.9 & 1 & 0 & 0 & 0 & 0 & 0 \\
Lipat-Kin & 8.2 & 32.4 & 23.4 & 12.3 & 9.8 & 8.5 & 3.7 & 0.9 & 0.8 & 0 & 0 & 0 & 0 \\
Horizontal-30 & 34.4 & 52.7 & 12.8 & 0 & 0 & 0 & 0 & 0 & 0 & 0 & 0 & 0 & 0 \\
Horizontal-60 & 14.8 & 30.5 & 23.5 & 17.7 & 4.7 & 5.1 & 3.7 & 0.2 & 0 & 0 & 0 & 0 & 0 \\
Horizontal-90 & 14.1 & 32.2 & 23.6 & 16.3 & 4.7 & 5.4 & 3.6 & 0.1 & 0 & 0 & 0 & 0 & 0 \\
Horizontal-Kin & 14.8 & 30.5 & 23.5 & 17.7 & 4.7 & 5.1 & 3.7 & 0.2 & 0 & 0 & 0 & 0 & 0 \\
Vertikal-60Tim & 38.2 & 50 & 11.8 & 0 & 0 & 0 & 0 & 0 & 0 & 0 & 0 & 0 & 0 \\
Vertikal-30Tim & 31.9 & 56.2 & 11.9 & 0 & 0 & 0 & 0 & 0 & 0 & 0 & 0 & 0 & 0 \\
Vertikal-90 & 42.4 & 45.6 & 11.5 & 0 & 0 & 0 & 0 & 0 & 0 & 0 & 0 & 0 & 0 \\
Vertikal-30Brt & 89.1 & 9.5 & 1.4 & 0 & 0 & 0 & 0 & 0 & 0 & 0 & 0 & 0 & 0 \\
Vertikal-60Brt & 23.1 & 19.9 & 15.5 & 8.9 & 7 & 5.8 & 6 & 6.6 & 5.1 & 2 & 0 & 0 & 0 \\
Vertikal-Kin & 23.1 & 19.9 & 15.5 & 8.9 & 7 & 5.8 & 6 & 6.6 & 5.1 & 2 & 0 & 0 & 0 \\
\hline
\end{tabular}

Gambar 8. Hasil simulasi aliran udara.

\section{Hasil Penghasilan Energi}

Yang dapat ditemukan dari hasil simulasi penghasilan energi adalah sistem kinetik overhang, sirip horizontal, dan sirip vertikal dapat menghasilkan jumlah energi lebih tinggi dari pada sistem 
statis, sedangkan sistem lipat menghasilkan paling rendah (Gambar 9). Sistem kinetik dari setiap tipe menghasilkan lebih banyak energi daripada sistem statis, tetapi sistem overhang, lipat, dan sirip horizontal dengan pengaturan sudut 30 dan 60 sangat mendekati sistem kinetik. Sistem sirip vertikal dapat menghasilkan peningkatan mendekati $70 \%$, dan peningkatan $43 \%$ dibandingkan yang terbaik dari sistem statis.

Secara keseluruhan hasil menunjukkan adanya peningkatan pada tiga dari empat sistem terhadap sistem photovoltaic standard, sedangkan sistem lipat menunjukkan penurunan penghasilan energi. Hal ini menunjukkan bahwa dengan menggerakkan panel sehingga mendapatkan sinar matahari secara langsung sepanjang hari lebih baik dari pada menggerakkan panel yang mengikuti pergerakan matahari secara tahunan. Peningkatan efisiensi yang didapatkan sebanyak hampir $35 \%$.

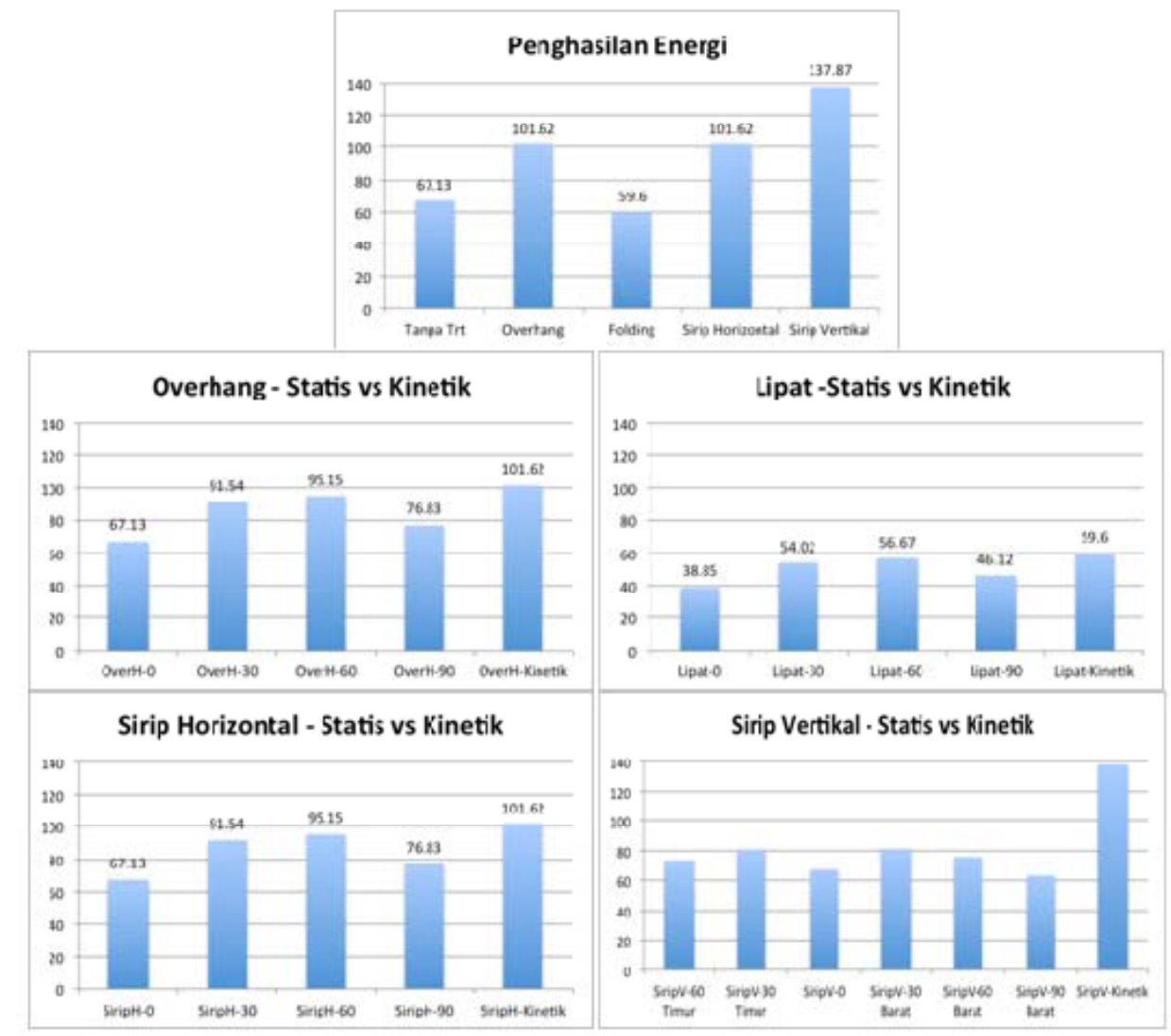

Gambar 9. Hasil simulasi penghasilan energi.

\section{PENUTUP}

Berdasarkan keempat hasil simulasi dapat disimpulkan bahwa efektifitas teritisan dengan sistem kinetik terhadap faktor lingkungan dibandingkan dengan sistem biasa dan statis dapat dilihat peningkatan terbesar dari faktor solar thermal dan daylighting. Efektifitasnya terhadap faktor penghasilan energi hanya dapat dilihat peningkatan pada beberapa sistem, sedangkan efektifitasnya terhadap faktor aliran udara hanya terlihat sedikit peningkatan.

Untuk itu dapat dikatakan secara hirarki bahwa keunggulan dari sistem kinetik adalah terhadap faktor suhu dan pencahayaan, dari faktor penghasilan energi memiliki sedikit keunggulan, sedangkan dari faktor aliran udara bisa dikatakan tidak terlalu diunggulkan. 
Sebagai penerapan yang dapat dilakukan dari penelitian ini untuk pengembangan selanjutnya adalah merancang teritisan kinetik yang mengintegrasikan keunggulan-keunggulan yang didapat dari hasil penelitian ini. Sebagai rekomendasi dan acuan yang bisa digunakan dalam merancang teritisan kinetik adalah Sistem overhang untuk mengurangi masalah panas matahari, sirip vertikal untuk memaksimalkan pencahayaan alami dan efektifitas photovoltaic, serta jendela standar untuk aliran udara yang baik. Rancangan yang dapat diasumsikan untuk kemudian diteliti lagi lebih lanjut adalah dengan mengkombinasikan beberapa jenis sistem kedalam satu bentuk teritisan kinetik dibawah ini (Gambar 10).
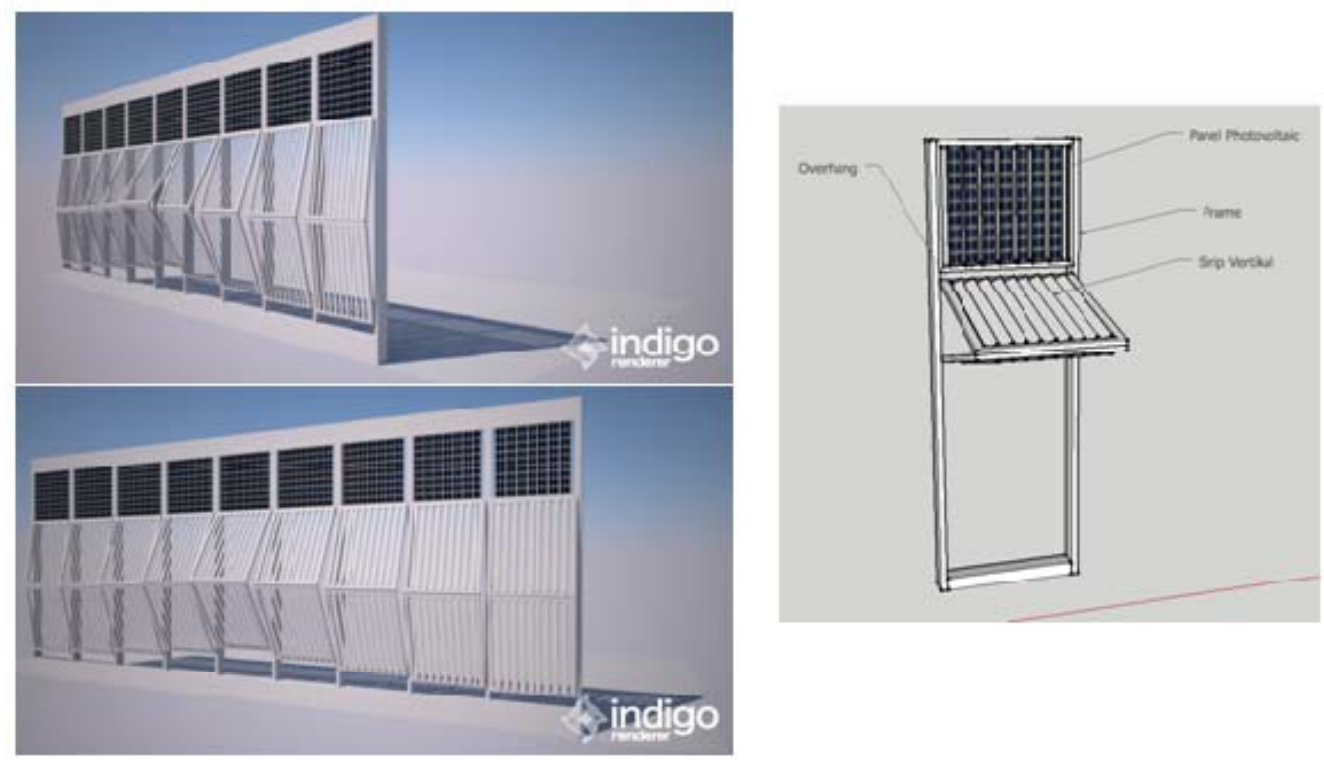

Gambar 10. Contoh alternatif pengembangan rancangan sistem teritisan kinetik.

\section{DAFTAR PUSTAKA}

Bougdah, H. and Sharples, S. (2010). Environment, Technology and Sustainability. London: Taylor \& Francis.

Fox, Michael. (2001). Beyond Kinetic. Cambridge: MIT.

Kensek, Karen. (2011). Environment Control Systems for Sustainable Design: A Methodology for Testing, Simulating and Comparing Kinetic Facade Systems. Journal of Creative Sustainable Architecture \& Built Environment (CSABE), 1.

Moloney, James. (2007). A Framework for the Design of Kinetic Facades. Computer Aided Design Futures (CAAD Futures), p.461-474.

Neufert, Ernst \& Neufert, Peter. (2007). Architects’ Data, (3rd ed.), Oxford: Blackwell Science. 